\title{
Heterogeneous Catalysts Using Strontium Oxide Agglomerates Depositing upon Titanium Plate for Enhancing Biodiesel Production
}

\author{
Han Lee ${ }^{1}$, Wen-Hao Wu ${ }^{1}$, Bing-Hung Chen ${ }^{2}{ }^{-}$and Jiunn-Der Liao ${ }^{1,3, *}$ \\ 1 Department of Materials Science and Engineering, National Cheng Kung University, No. 1, University Road, \\ Tainan 701, Taiwan; 10608102@gs.ncku.edu.tw (H.L.); n56081446@gs.ncku.edu.tw (W.-H.W.) \\ 2 Department of Chemical Engineering, National Cheng Kung University, 1 University Road, \\ Tainan 701, Taiwan; bkchen@mail.ncku.edu.tw \\ 3 Medical Device Innovation Center, National Cheng Kung University, 1 University Road, Tainan 701, Taiwan \\ * Correspondence: jdliao@mail.ncku.edu.tw; Tel.: +886-6-275-7575 (ext. 62971); Fax: +886-6-234-6290
}

Citation: Lee, H.; Wu, W.-H.; Chen, B.-H.; Liao, J.-D. Heterogeneous Catalysts Using Strontium Oxide Agglomerates Depositing upon Titanium Plate for Enhancing Biodiesel Production. Catalysts 2021, 11,30. https://doi.org/10.3390/ catal11010030

Received: 16 December 2020 Accepted: 25 December 2020 Published: 30 December 2020

Publisher's Note: MDPI stays neutral with regard to jurisdictional clai$\mathrm{ms}$ in published maps and institutional affiliations.

Copyright: (C) 2020 by the authors. Licensee MDPI, Basel, Switzerland. This article is an open access article distributed under the terms and conditions of the Creative Commons Attribution (CC BY) license (https:// creativecommons.org/licenses/by/ $4.0 /)$.

\begin{abstract}
Strontium oxide ( $\mathrm{SrO}$ ) is an effective catalyst for transesterification. $\mathrm{SrO}$ powder that is firmly deposited onto a light titanium plate $\left(\mathrm{TiO}_{2} \mathrm{P}\right)$, denoted as $\mathrm{SrO} / \mathrm{TiO}_{2} \mathrm{P}$, can be reinforced by forming strontium titanate $\left(\mathrm{SrTiO}_{3}\right)$ at the interface. Exposed $\mathrm{SrO}$ agglomerates can promote subsequent continuous transesterification process. In this work, conversion efficiency and production of biodiesel from olive oil on $\mathrm{SrO} / \mathrm{TiO}_{2} \mathrm{P}$ is investigated. The as-designed $\mathrm{SrO} / \mathrm{TiO}_{2} \mathrm{P}$ was followed by dip-coating and heat treatment. The physical properties of $\mathrm{SrO} / \mathrm{TiO}_{2} \_\mathrm{P}$ were verified through ASTM D3359; the chemical structures before and after transesterification, were respectively identified by X-ray photoelectron spectroscopy and Raman spectroscopy. A focused microwave heating system was utilized for transesterification. In the optimized sample $\mathrm{SrO} / \mathrm{TiO}_{2} \mathrm{P}(\mathrm{x})(\mathrm{x}=0.5 \mathrm{M})$, $\mathrm{SrO}$ firmly bonds with $\mathrm{TiO}_{2} \mathrm{P}$ and forms the $\mathrm{SrTiO}_{3}$ structure. With the support of $\mathrm{TiO}_{2-} \mathrm{P}$, the tested oil with $\mathrm{SrO}$ agglomerates subsequently reacts with $\mathrm{SrO}$ under microwave heating. The biodiesel conversion rate reaches $87.7 \%$ after a reaction time of $4 \mathrm{~min}$, while the biodiesel product has an average of $39.37 \mathrm{MJ} / \mathrm{kg}$ of combustion heat and less than $1 \mathrm{vol} \%$ of water content. The as-designed $\mathrm{SrO} / \mathrm{TiO}_{2} \mathrm{P}$ (0.5) thus has great potential for biodiesel production and is promising with high stability in particular for a continuous fluid flow system.
\end{abstract}

Keywords: strontium oxide $(\mathrm{SrO})$; titanium plate $\left(\mathrm{TiO}_{2} \mathrm{P}\right)$; transesterification process; biodiesel production; microwave heating system

\section{HIGHLIGHTS:}

- Titanium powder is formed into a $\mathrm{TiO}_{2}$ plate $\left(\mathrm{TiO}_{2} \mathrm{P}\right)$ as a load-bearable support and designed to integrate with catalytic $\mathrm{SrO}$ agglomerates.

- The synergic effect of $\mathrm{SrO} / \mathrm{TiO}_{2} \mathrm{P}$ is realized by forming $\mathrm{SrTiO}_{3}$ phase at their interface and $\mathrm{SrO}$ agglomerates upon the surface.

- By applying focused microwave heating, the exposed $\mathrm{SrO}$ agglomerates and olive oil are effectively interacted by transesterification reaction.

- The quality of the as-produced biodiesel is examined by the characteristic Raman peak, conversion rate, combustion heat, and water content.

- The used $\mathrm{SrO} / \mathrm{TiO}_{2} \mathrm{P}$ is mostly re-cyclable for subsequent uses, which reduced the wastes when the biodiesel is produced.

\section{Introduction}

It has been noted that circular economy where nothing is wasted and where natural resources are managed sustainably and biodiversity is protected [1,2]. In the recent development, waste management originated on the realization of a circular economy is 
eventually to reduce, reuse, and recycle wastes [3]. Alternatively, due to the economic benefits, one of green energies using a recycled resource has attracted more and more attention $[4,5]$. In the past decades, a significant portion of the energy demand for electricity generation has been met through the combustion of fossil fuels. The emission of hazardous substances such as $\mathrm{NO}_{x}, \mathrm{HC}$, smoke, $\mathrm{CO}$, and $\mathrm{SO}_{x}$ is widely concerned. Biodiesel is an eco-friendly alternative; it can be prepared from waste oil $[6,7]$ or less economically used plants [8-10] without changing the existing engines or generators [11,12]. As reported from Brazil, Germany, France, the United States of America, and Belgium, biodiesel is considered to have the unprecedented potentiality for endurable renewable energy applications in the future [13-15].

In fact, biodiesel is one of the promising alternatives as a kind of biofuels, especially when non-edible feedstocks are used in the production process [16]. Currently, there are many methods that have been provided for the generation of biodiesel resources [16,17]. For examples, they can be made by direct use and blending of raw oil [18], micro-emulsions [19], thermal cracking [20], and transesterification [16,21,22]. For the direct use and blending of raw oil, a condition of liquid nature-portability is applied for a heat content of $\sim 80 \%$ from diesel fuel, which is relatively spectacular. However, because it easily deteriorates and loses its volatility, it is difficult to consider for practical use [18]. Micro-emulsions are considered to be a colloidal equilibrium dispersion of an optically isotropic fluid microstructure with a size usually in the range of $1-150 \mathrm{~nm}$ formed naturally from two kinds of immiscible fluids and one or even more ionic or non-ionic amphiphile substances [19,23]. However, when using this method, the cetane number and energy content are insufficient that make it not suitable for the subsequent application, wherein an irregular injector needle may cause stickiness and insufficient fluidity, leading to incomplete combustion [19]. Transesterification mainly works as the interaction between a solid fat or liquid oil and alcohol under a catalyst used to generate glycerol and esters [24,25]. Additionally, by the selection of microwave heating process, less reaction time and purer products can be achieved [26,27]. For example, the microwave-assisted reaction rate is enhanced by an extremely high value of around five to one thousand times comparing with traditional heating methods $[28,29]$. Therefore, transesterification with the assistance of microwave heating highly focuses on reliability and high cetane number that indicates a fast fuel burning process and makes somewhat flammable; it is thus an efficient way to prepare an energy resource.

In various transesterification reactions, homogeneous acidic catalysts [30], and alkaline catalysts $[30,31]$ are commonly used. However, these methods are sensitive to impurities found in oils such as free fatty acids and water [32]. For instances, liquid acid and base catalysts are corrosive and difficult to be recycled (i.e., homogeneous catalysts such as $\mathrm{H}_{2} \mathrm{SO}_{4}$ and $\mathrm{KOH}$ ). The production cost is greatly increased by the complicated processing steps and costly anticorrosive facilities. In addition, large amounts of waste catalysts and water are formed, which have seriously polluted our environment. Moreover, potassium hydroxide catalysts have a characteristic of good solubility to be used as biodiesel fuel and its common byproduct, glycerin, makes it difficult to be purified and therefore lowers their practical efficiency [32-34]. The lifetimes of the engine and exhaust system are likely shortened by burning alkali and acid contaminated fatty acid methyl esters (FAME) products $[35,36]$. Therefore, to overcome the technical shortcomings associated with conventional catalysts for the production of biodiesel, a great deal of research has been conducted to develop heterogeneous catalysts [37]. A solution for these problems has been found in the application of heterogeneous catalysts such as alkali metal oxides as neat or loaded on the support. Their advantages over homogeneous catalysts refer to easy separation from the reaction mixture and the possibility to be reused, selectivity and longer catalyst lifetimes $[38,39]$. Since recently, the heterogeneous catalysts have been improved by loading a metal onto the catalyst surface to increase its hydrophobicity, which prevents the absorption of generated water during the reaction and contributes to the catalyst stability [40]. 
Since the transesterification reaction involves the presence of alcohol, it is worthwhile to determine its quantity with respect to the other reactant or oil. A proper ratio of oil: methanol in 1:6 has been developed [41]. In addition, a $3 \mathrm{wt} \%$ of catalyst as $\mathrm{SrO}$ in terms of oil weight has been particularly used [16,42]. For most supported alkali catalysts, the active ingredients are easily corroded by methanol and they exhibit short catalyst lifetimes. For examples, $\mathrm{BaO}$ is noxious and can be dissolved by methanol [43]; $\mathrm{MgO}$ has low activity in transesterification of vegetable oils to biodiesel [44]; and $\mathrm{CaO}$ provides a slow reaction rate and it takes about $2 \mathrm{~h}$ to reach a state of equilibrium [45]. On the other hand, $\mathrm{SrO}$ takes some advantages: it can catalyze many chemical reactions, such as oxidative coupling of methane, selective oxidation of propane, nitroaldol reactions, and mixed reactions. Further, it is insoluble in methanol, vegetable oils, and fatty acid methyl ester. Therefore, $\mathrm{SrO}$ is relatively suitable for our study [38].

With an increasing demand for transesterification reaction efficiency, SrO has been designed to be deposited upon bead- or plate-like supports. For examples, SrO particles were deposited into $\mathrm{SiO}_{2}$ composite, followed by microwave heating for biodiesel production [38]. The strong adhesion of $\mathrm{SrO}$ on silica beads would allow the use of the catalyst in a continuous flow microwave system facilitating production of large quantities of biodiesel. Similar approaches have been developed using activated carbon [46], $\mathrm{Al}_{2} \mathrm{O}_{3}$ [47] as the support for biodiesel production, in particular for the transesterification reaction from e.g., waste cooking oil. Our previous studies used a highly porous and calcinated scaffold that provides load-bearable support for a continuous process, while the calcinated SrO catalyst, as it is well distributed inside the porous matrix, could extend its surface contact area with the reactants. In these studies, a microwave heating system for the transesterification reaction was particularly introduced to increase the reaction efficiency [17].

In this study, $\mathrm{SrO}$ powder deposited upon a titanium plate is designed. The titanium plate is chosen as the support owing to likely formation of strontium titanate $\left(\mathrm{SrTiO}_{3}\right)$ at their interface after heat treatment. The as-formed $\mathrm{SrO}$ upon $\mathrm{TiO}_{2}$ plate is then examined to be load-bearable during the transesterification process. The production and quality of biodiesel are also assessed. Thereafter, a transesterification reaction mechanism based upon the assessments is proposed.

\section{Results and Discussion}

\subsection{Physical Properties of the Surface of $\mathrm{SrO}_{\mathrm{TiO}}{ }_{2} \mathrm{P}(x)$}

Surface morphologies of $\mathrm{SrO} / \mathrm{TiO}_{2} \_\mathrm{P}(\mathrm{x})(\mathrm{x}=0.1,0.3,0.5$, or $0.7 \mathrm{M})$ were respectively shown in Figure 1a-d; the top-right images were taken from EDS element mapping, while the red color is the distribution of the element Sr. The results indicated that the coverage of Sr element increased with the added concentration of Sr-containing solution. Surface morphology of $\mathrm{SrO}$ clusters exhibited a broccoli shape aggregated structure.

XRD patterns of $\mathrm{SrO} / \mathrm{TiO}_{2} \mathrm{P}(\mathrm{x})(\mathrm{x}=0.1,0.3,0.5$, or $0.7 \mathrm{M})$ were respectively shown in Figure 1e. Note that according to JCPDS card No. 06-0520, the cubic-SrO can be found in the $2 \theta$ diffraction range of 30 to $65^{\circ}$, corresponding to (111), (200), (220), (311), and (222); according to JCPDS card No. 35-0734, the cubic-SrTiO 3 can be found in the $2 \theta$ diffraction range of $23^{\circ}$ and $73^{\circ}$ [48], corresponding to (100), (110), (111), (200), (211), (220), and (300). The results indicated that for $\mathrm{SrO} / \mathrm{TiO}_{2} \mathrm{P}(\mathrm{x})$, SrO structure was found on all the surfaces, whereas $\mathrm{SrTiO}_{3}$ could only be found on lower concentrations, i.e., $\mathrm{x}=0.1,0.3$, or $0.5 \mathrm{M}$. Based on the XRD pattern found in $\mathrm{SrO} / \mathrm{TiO}_{2} \mathrm{P}(0.7)$, the peaks for cubic-SrO were much significant, therefore the pattern for cubic-SrTiO 3 (i.e., under the coverage of cubic-SrO structure) was most likely shaded by the coverage of $\mathrm{SrO}$ aggregates [49]. The results correspond well with the surface morphologies presented in Figure 1a-d.

In Figure 1f, the surface roughness of $\mathrm{SrO} / \mathrm{TiO}_{2} \_\mathrm{P}(\mathrm{x})$ was measured. The profiles showed that their roughness increased with the addition of $\mathrm{SrO}$ aggregates. However, for $\mathrm{SrO} / \mathrm{TiO}_{2} \_\mathrm{P}(0.7)$, the coverage of $\mathrm{SrO}$ aggregates was significant that reduced the surface area or therefore the average roughness. 

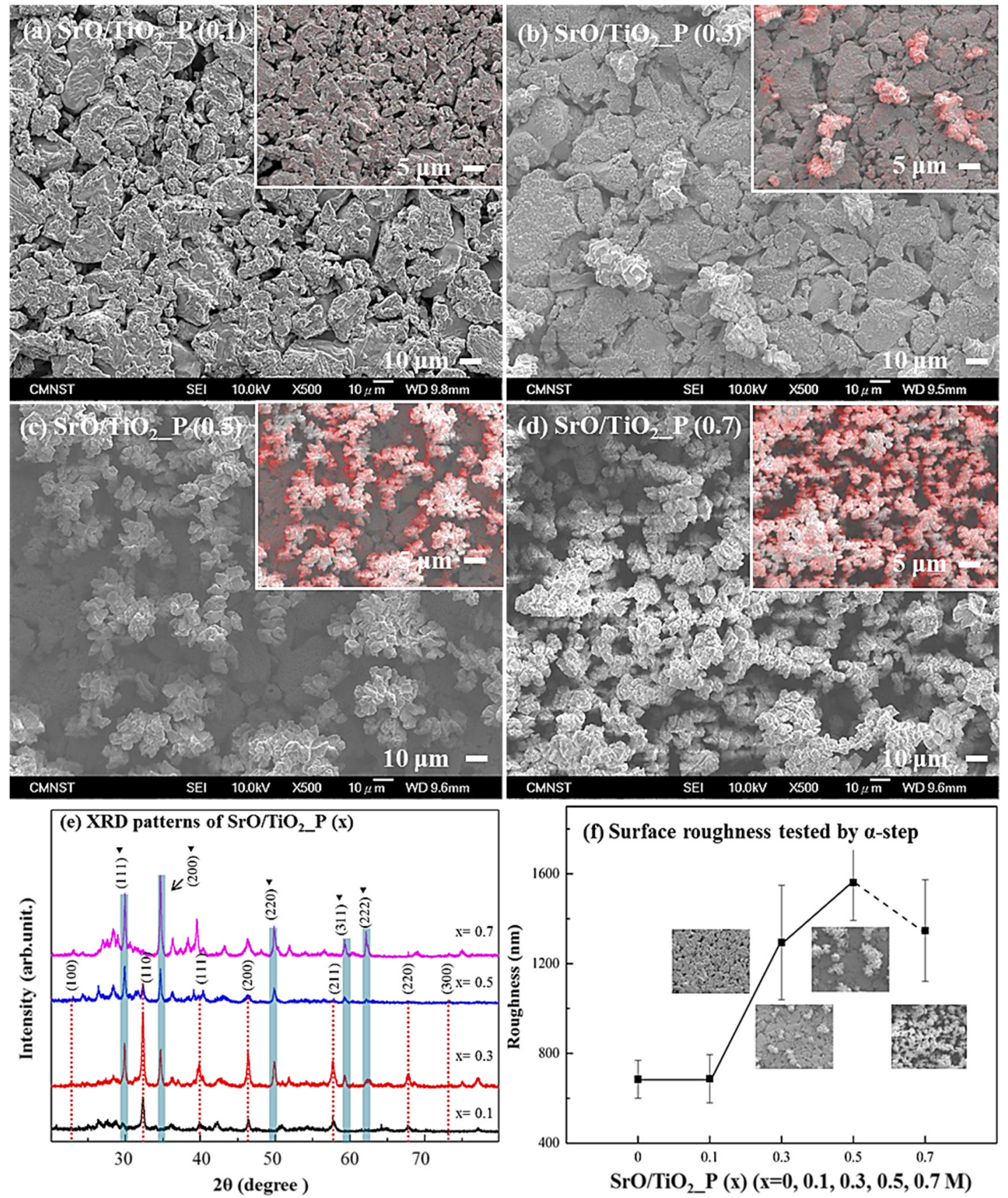

Figure 1. SEM morphologies from the surfaces of $\mathrm{SrO}_{-} \mathrm{TiO}_{2} \_\mathrm{P}(\mathrm{x}), \mathrm{x}=(\mathbf{a}) 0.1,(\mathbf{b}) 0.3,(\mathbf{c}) 0.5$, and (d) 0.7. (e) XRD patterns and (f) surface roughness of $\mathrm{SrO}_{-} \mathrm{TiO}_{2} \mathrm{P}(\mathrm{x})$ were measured.

\subsection{Chemical Analysis on the Surfaces of $\mathrm{SrO}_{\mathrm{TiO}} \mathrm{T}_{2} P(x)$}

In Figure 2a, XPS survey spectra of $\mathrm{SrO} / \mathrm{TiO}_{2} \mathrm{P}(\mathrm{x})$ showed the presence of $\mathrm{Sr}, \mathrm{Ti}, \mathrm{C}$, and $\mathrm{O}$ elements. Note that the adsorbed $\mathrm{C}, \mathrm{O}$-containing species is minor, therefore only $\mathrm{Sr}$ $3 \mathrm{~d}$, $\mathrm{Ti} 2 \mathrm{p}$, and $\mathrm{O} 1 \mathrm{~s}$ spectra are studied for $\mathrm{SrO} / \mathrm{TiO}_{2} \mathrm{P}(\mathrm{x})$ before the transesterification reaction, whereas for $\mathrm{SrO} / \mathrm{TiO}_{2} \_\mathrm{P}(\mathrm{x})$ after the reaction $\mathrm{Sr} 3 \mathrm{~d}, \mathrm{C}$ 1s, and $\mathrm{O}$ 1s spectra are studied owing to the surface of $\mathrm{TiO}_{2} \mathrm{P}$ is covered by the reactants and products.

In Figure $2 b$, Sr $3 d$ spectra for $\mathrm{SrO} / \mathrm{TiO}_{2} \_\mathrm{P}(\mathrm{x})$ were deconvoluted into $\mathrm{Sr} 3 \mathrm{~d} 5 / 2$ and Sr $3 \mathrm{~d} 3 / 2$ at binding energies (BEs) of 132.9 (peak (1)) and $134.6 \mathrm{eV}$ (peak (2)) with the difference of $1.7 \mathrm{eV}$. The intensity and the area of $\mathrm{Sr} 3 \mathrm{~d} 5 / 2$ and $3 \mathrm{~d} 3 / 2$ spectra increased with the addition of concentrations. In Figure 2c, Ti $2 p$ spectra were deconvoluted into Ti 2p3/2 and $2 \mathrm{p} 1 / 2$ at 458.6 (peak (3)) and $464.3 \mathrm{eV}$ (peak (4)) with the difference of $5.7 \mathrm{eV}$, indicated 
that $\mathrm{Ti}^{4+}$ is the dominant surface chemical state, which corresponded to the formation of $\mathrm{TiO}_{2}$ or probably $\mathrm{SrTiO}_{3}$ phase. The intensity and area of $\mathrm{Ti} 2 \mathrm{p}$ spectra decreased with the addition of $\mathrm{SrO}$ concentrations. In Figure $2 \mathrm{~d}, \mathrm{O} 1 \mathrm{~s}$ spectra were deconvoluted into BEs peaked at $529.2 \mathrm{eV}$ (peak (5)) for $\mathrm{SrTiO}_{3}, 530.5 \mathrm{eV}$ (peak (6)) for $\mathrm{SrO}$, and $532.0 \mathrm{eV}$ (peak (7)) for $\mathrm{M}-\mathrm{OH}$. Note that the peaks (3) and (5) represent the presence of $\mathrm{SrTiO}_{3}$, which exhibit obvious as $\mathrm{SrO}$ coverage is minor [50]. In addition, $\mathrm{M}-\mathrm{OH}$ species may derivate from the metal-hydroxide group during the preparation process in the ambient atmosphere [51].
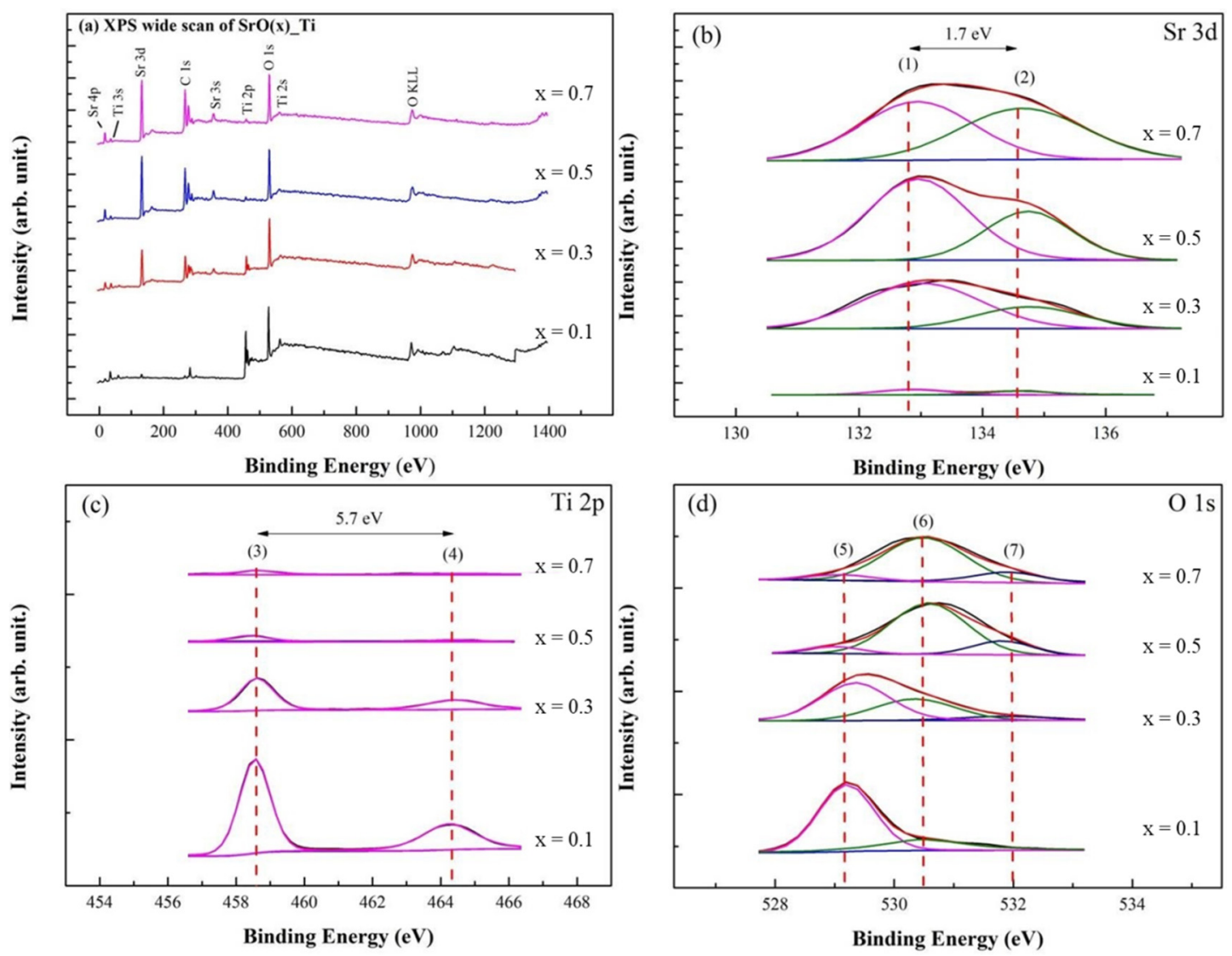

Figure 2. XPS studies of $\mathrm{SrO}_{-} \mathrm{TiO}_{2} \_\mathrm{P}(\mathrm{x})(\mathrm{x}=0.1,0.3$. 0.5 , or 0.7$)$ before transesterification process were demonstrated: (a) Wide-scan XPS spectra and (b) curve-fitted XPS spectra for Sr 3d, (c) Ti 2p, and (d) O 1s. The curve-fitted peaks are respectively assigned at: (1) $132.9 \mathrm{eV}$, Sr 3d5/2, (2) $134.6 \mathrm{eV}$, Sr 3d3/2, (3) $458.6 \mathrm{eV}$, Ti 2p3/2, (4) 464.3 eV, Ti 2p1/2, (5) $529.2 \mathrm{eV}, \mathrm{Sr}-\mathrm{Ti},(6) 530.5 \mathrm{eV}, \mathrm{Sr}-\mathrm{O}$, and (7) $532.0 \mathrm{eV}$, loosely bound hydroxide groups.

\subsection{Biodiesel Conversion for Products}

Based on the evaluation of surface morphologies, XRD patterns, surface roughness, and XPS spectra of $\mathrm{SrO} / \mathrm{TiO}_{2} \_\mathrm{P}(\mathrm{x}), \mathrm{SrO} / \mathrm{TiO}_{2} \_\mathrm{P}(0.5)$ is an optimized sample for subsequent studies.

In Figure 3a, XPS survey spectra of $\mathrm{SrO} / \mathrm{TiO}_{2} \_\mathrm{P}(0.5)$, after the transesterification reaction time of $1,2,3$, and $4 \mathrm{~min}$ (i.e., the duration for microwave heating), showed the major presence of $\mathrm{Sr}, \mathrm{C}$, and $\mathrm{O}$ elements. Note that after the reactions, the surfaces of $\mathrm{TiO}_{2} \mathrm{P}$ is covered by the reactants and products. In Figure $3 \mathrm{~b}, \mathrm{Sr} 3 \mathrm{~d}$ spectra for $\mathrm{SrO} / \mathrm{TiO}_{2} \mathrm{P}(\mathrm{x})$ showed similar peaks and $\mathrm{BEs}$ with $\mathrm{SrO} / \mathrm{TiO}_{2} \mathrm{P}(0.5)$ in Figure $2 \mathrm{~b}$. The results indicated that the structure $\mathrm{SrO}$ still remains after the reaction time. The intensity and the area of $\mathrm{Sr}$ $3 \mathrm{~d} 5 / 2$ and $3 \mathrm{~d} 3 / 2$ spectra significantly decreased with the reaction time of $4 \mathrm{~min}$, indicating the addition of reactants and products. In Figure $3 \mathrm{c}, \mathrm{C} 1 \mathrm{~s}$ spectra were deconvoluted into three component spectra with the peaks $3^{\prime}$ at $284.8 \mathrm{eV}(\mathrm{C}-\mathrm{C}), 4^{\prime}$ at $287.1 \mathrm{eV}(\mathrm{C}-\mathrm{O})$, and $5^{\prime}$ at $289.2 \mathrm{eV}(\mathrm{O}-\mathrm{C}=\mathrm{O})$ [17]. The peaks intensity roughly increased with the addition of reaction time, except for the reaction time of $4 \mathrm{~min}$. The main chemical contributions of $\mathrm{C}$ 
1s peaks for biodiesel (FAME) compounds correspond to peaks $3^{\prime}$ and $5^{\prime}$. In addition, the spectrum of FAME (a methyl ester) has the characteristic $-\mathrm{O}^{-} \mathrm{CH}_{3}$ peak $6^{\prime}$ [52] at $287.1 \mathrm{eV}$. In Figure 3d, O 1s spectra were deconvoluted into five peaks, in which the peak $6^{\prime}$ at $530.5 \mathrm{eV}$ is correlated with $\mathrm{Sr}-\mathrm{O}$, and the peaks $7^{\prime}$ at $531.0 \mathrm{eV}$ with $\mathrm{C}-\mathrm{O}$ (or C $1 \mathrm{~s}$ at $287.1 \mathrm{eV}$ ), $9^{\prime}$ at $532.8 \mathrm{eV}$ with $\mathrm{C}=\mathrm{O}$ [53], and $10^{\prime}$ at $533.7 \mathrm{eV}$ with $\mathrm{O}-\mathrm{C}=\mathrm{O}$ (or $\mathrm{C} 1 \mathrm{~s}$ at $289.2 \mathrm{eV}$ ). The latter three component peaks represent the formation of FAME. The peak $8^{\prime}$ at $532.0 \mathrm{eV}$ is correlated with $\mathrm{M}-\mathrm{OH}$, corresponding with the peak 7 in Figure 2d. Overall, the chemical analysis by XPS, before and after the transesterification reaction and reaction time, is almost interrelated.
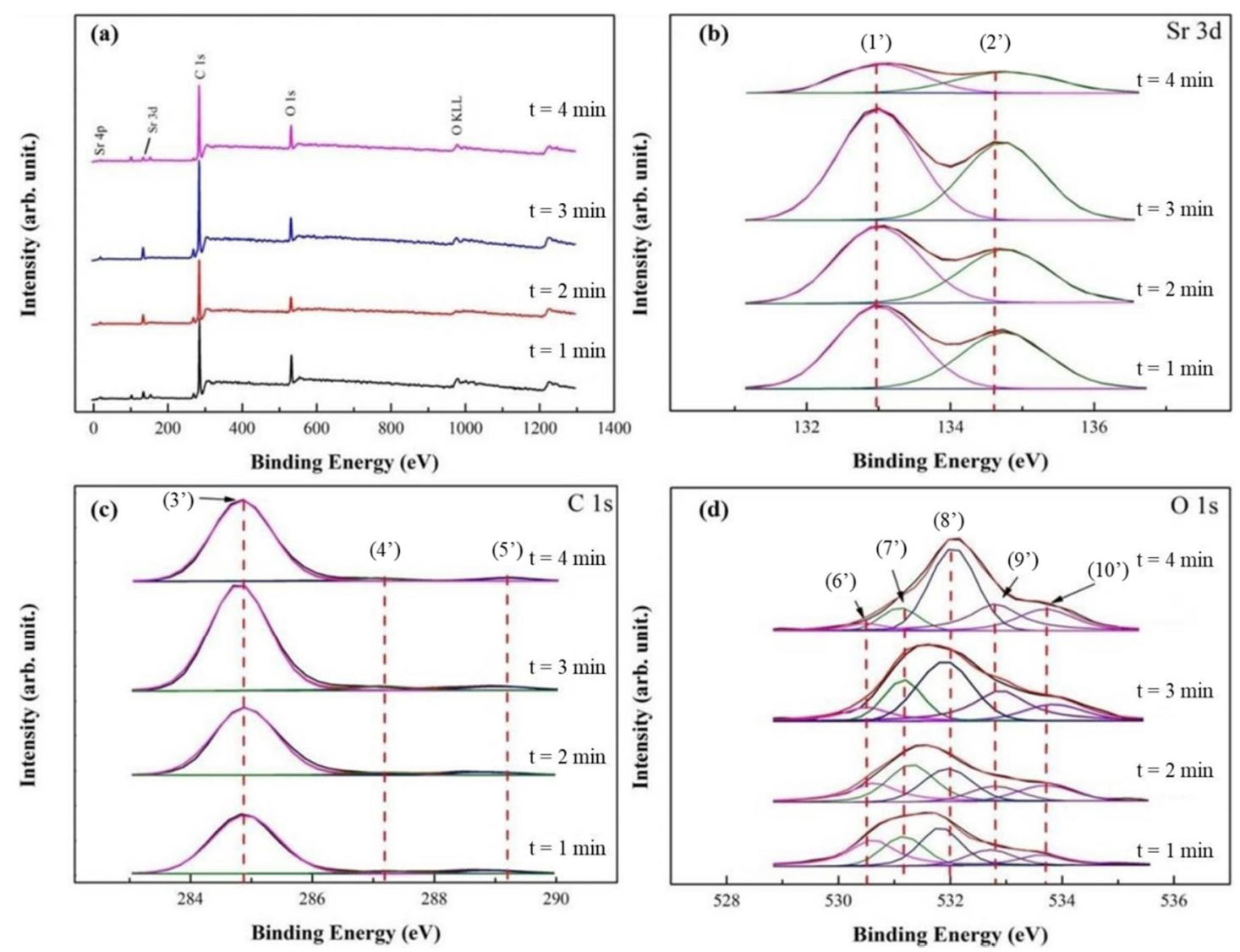

Figure 3. XPS studies of $\mathrm{SrO}_{-} \mathrm{TiO}_{2} \mathrm{P}(0.5)$ after transesterification process with different reaction time $(\mathrm{t}, \mathrm{t}=1,2,3$, or 4 min) were demonstrated: (a) wide-scan XPS spectra and (b) curve-fitted XPS spectra with different reaction time for (b) Sr 3d, (c) C 1s, and (d) O 1s. The curve-fitted peaks are respectively assigned at: (1) $132.9 \mathrm{eV}, \mathrm{Sr} 3 \mathrm{~d}_{5 / 2},(2) 134.6 \mathrm{eV}, \mathrm{Sr} 3 \mathrm{~d}_{3 / 2}$, (3) $284.8 \mathrm{eV}, \mathrm{C}-\mathrm{C}$, (4) $287.1 \mathrm{eV}, \mathrm{C}-\mathrm{O},(5) 289.2 \mathrm{eV}, \mathrm{O}=\mathrm{C}-\mathrm{O}$, (6) $530.5 \mathrm{eV}, \mathrm{Sr}-\mathrm{O},(7) 531.0 \mathrm{eV}, \mathrm{C}-\mathrm{O},(8) 532.0 \mathrm{eV}, \mathrm{M}-\mathrm{OH},(9) 532.8 \mathrm{eV}$, $\mathrm{C}=\mathrm{O}$, and (10) $533.7 \mathrm{eV}, \mathrm{O}-\mathrm{C}=\mathrm{O}$.

In Figure 4a, Raman spectra of olive oil before and after transesterification reaction were taken. The peak at $1655 \mathrm{~cm}^{-1}$ is frequently used as the indicator of FAME production $[54,55]$. By taking the peak as the reference, as the quantity of FAME production increased, the intensity of $1655 \mathrm{~cm}^{-1}$ reduced with the increasing reaction time; as estimated in Figure $4 \mathrm{a}$, the relative reduction in intensities from 24, 30, 30 to $41 \%$ with respect to the reaction time of 1, 2, 3, and 4 min was observed. In Figure $4 \mathrm{~b}$, the conversion efficiency of olive oil to biodiesel reached $87.7 \%$ after $4 \mathrm{~min}$ from the onset of the reaction; however, the relative increase in biodiesel conversion, as shown in lines, reached a maximum of $\sim 10 \%$ after $3 \mathrm{~min}$ of the reaction time, but sharply dropped to $\sim 2 \%$ after 4 min of the reaction time. It indicates two possibilities: (1) a reaction time over 3 min may result in an optimal increased rate of biodiesel conversion; (2) the conversion of olive oil into biodiesel near $\mathrm{SrO}$ agglomerates (or therefore at the oil/SrO interface) may reach a reaction limit. 

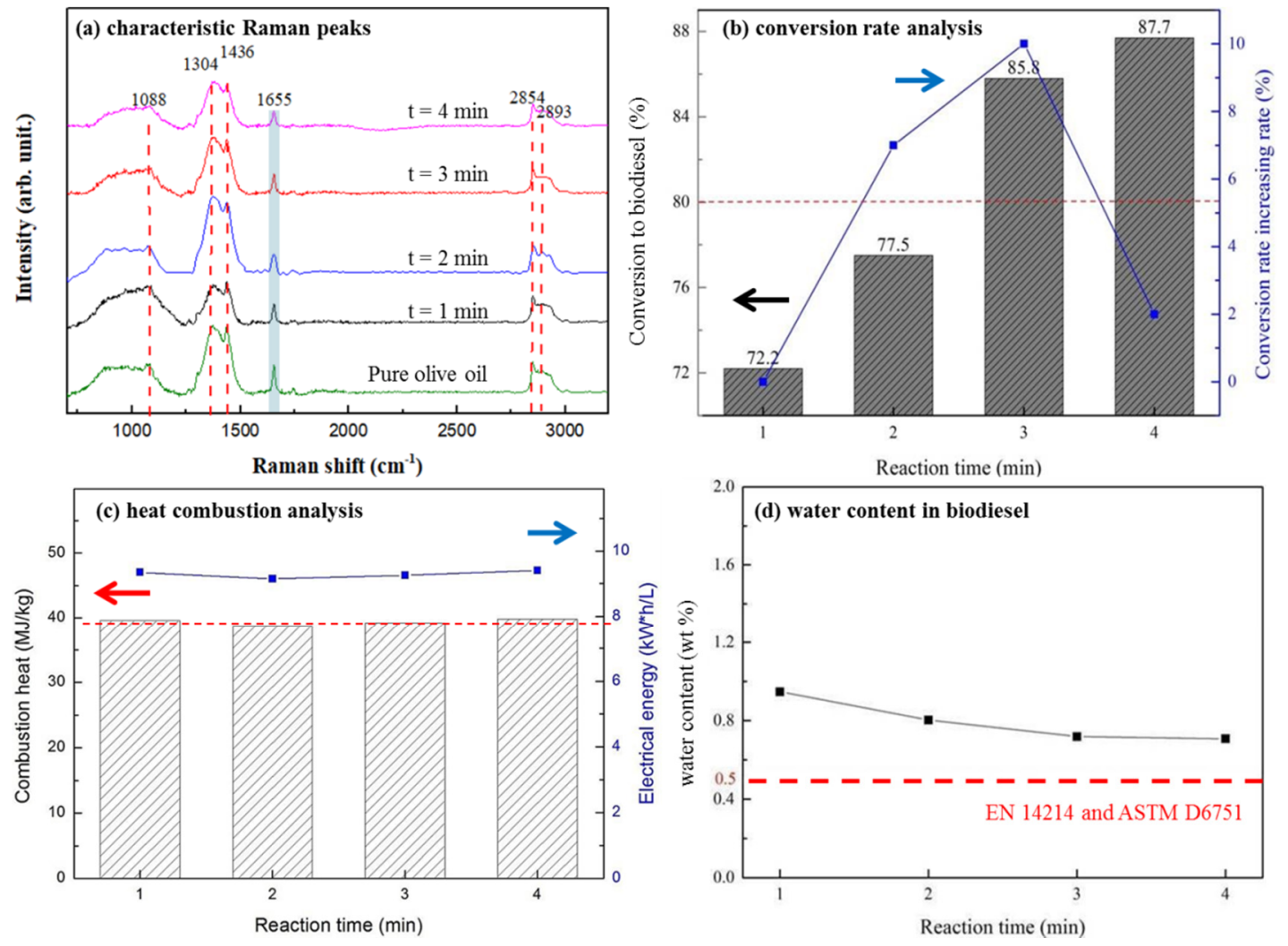

Figure 4. For $\mathrm{SrO} / \mathrm{TiO}_{2} \mathrm{P}(0.5)$ after transesterification process with different reaction time $(\mathrm{t}, \mathrm{t}=0$ (pure), 1, 2, 3, or 4 min), followed by different chemical analyses, (a) the characteristic Raman peaks at 1088, 1304, 1436, 1655, 2854, and 2893 cm $\mathrm{cm}^{-1}$ were distinguished; (b) biodiesel conversion rate (in \%) analysis are measured, (c) biodiesel heat combustion analysis, and (d) water content (in \%) in biodiesel were respectively determined.

The quality of as-produced biodiesel was measured. In Figure 4c, its combustion heat ranged from 39-42 MJ $/ \mathrm{kg}$ with an average value of $39.37 \mathrm{MJ} / \mathrm{kg}$, as compared with a general value of $42 \mathrm{MJ} / \mathrm{kg}$ for a general diesel [56]. In Figure $4 \mathrm{~d}$, the water content of the as-produced biodiesel was also estimated; its value was slightly higher than that specified in both EN 14214 and ASTM D6751 standards [57,58]. Nevertheless, by improving the storage and delivery procedures, it should be very likely to eliminate water content in biodiesel. In addition, oil with a high acid value tends to generate non-esterified fatty acids in the biodiesel products, which can deteriorate equipment components. In the case about waste cooking oil (WCO), the high percentage of water molecules in WCOs may inhibit the catalyst activity and the ability of methanol to separate triglycerides from WCOs. Moreover, the high quantity of non-esterified species in the products of methanol, biodiesel, and crude glycerol makes the solution sticky and increasingly reduces the biodiesel conversion rate with reaction time.

\subsection{Proposed Reaction Mechanism and Application}

By taking $\mathrm{SrO} / \mathrm{TiO}_{2} \mathrm{P}(0.5)$ as the example and reacting with olive oil by focused microwave heating for 1 to $4 \mathrm{~min}$, the reaction mechanism of transesterification process, followed by batch biodiesel production is presumably proposed. Firstly, as shown in Figure 5 a, SrO particles form agglomerates or clusters upon $\mathrm{TiO}_{2} \_\mathrm{P}(0.5)$, which are resistant to subsequent microwave heating and transesterification process. In Figure $5 b$, at the interface between $\mathrm{SrO}$ agglomerates and olive oil, biodiesel conversion is performed by an effective microwave heating that is characterized by XPS studies before and after the reaction. The structure of $\mathrm{SrTiO}_{3}$ binds the $\mathrm{SrO}$ agglomerates with $\mathrm{TiO}_{2} \mathrm{P}$ and $\mathrm{SrO}$ particles reaction with olive oil under microwave heating. In Figure $5 c$, the quality of the as-produced biodiesel, FAME, is examined by the characteristic Raman peak at $1655 \mathrm{~cm}^{-1}$, conversion 
rate, heat combustion heat, and water content and reported as a promising biodiesel through this production method. In addition, the by-products can be collected for other uses. In Figure $5 \mathrm{~d}$, by acetone or ethanol cleaning under ultrasonic vibration at $10 \mathrm{~min}$, the used $\mathrm{SrO} / \mathrm{TiO}_{2} \mathrm{P}(0.5)$ can be re-used for succeeding transesterification processes, re-starting from Figure $5 \mathrm{a}$, which becomes an innovative design as a re-cyclable and productive material. The information related recyclability of the catalyst could be found in our previous studies [16].

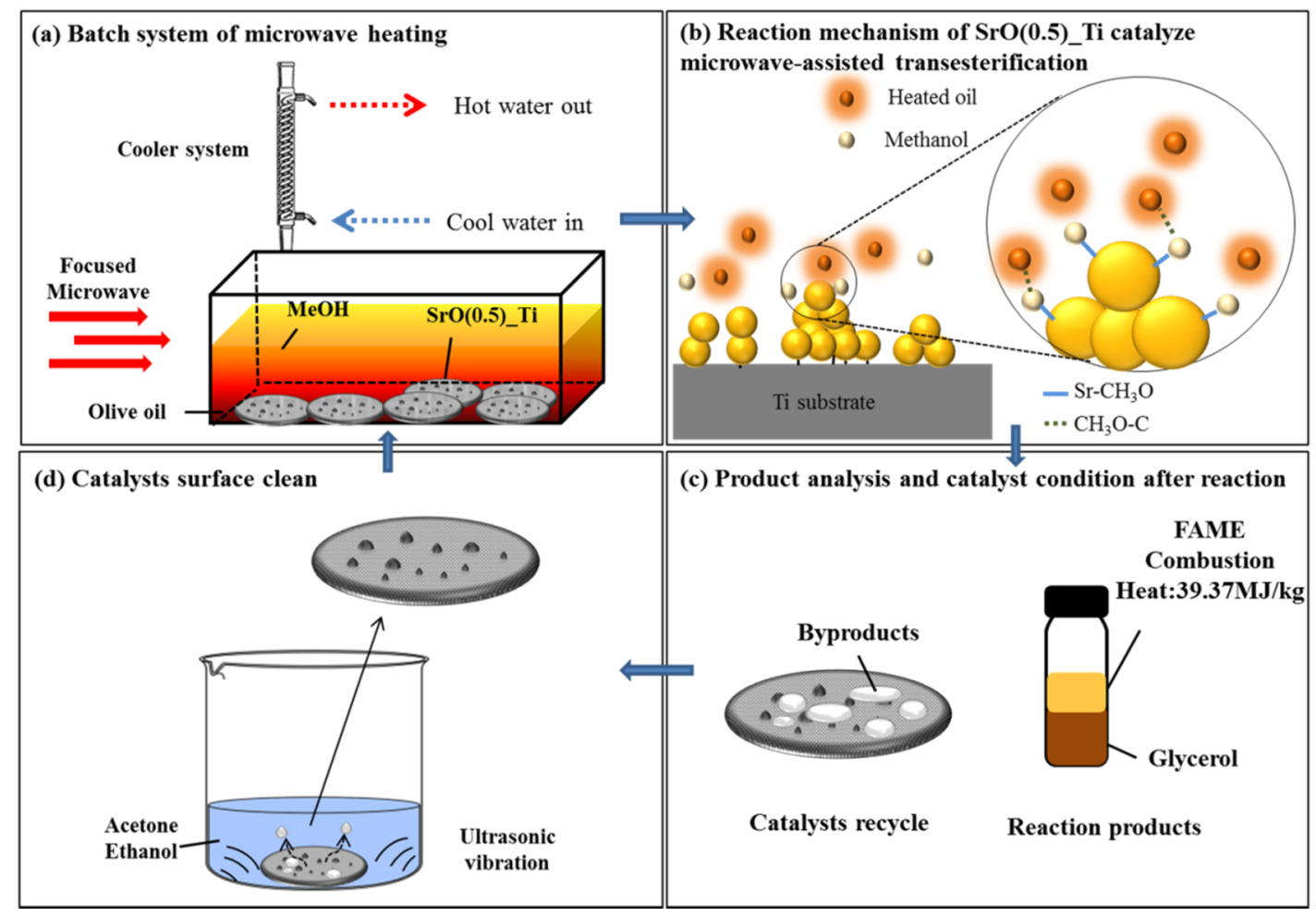

Figure 5. Summary of the transesterification process, reactions mechanism, and the management of reactants and products: (a) $\mathrm{SrO}$ particles form agglomerates or clusters upon $\mathrm{TiO}_{2} \mathrm{P}(0.5)$, which are resistant to subsequent microwave heating and transesterification process; (b) at the interface between $\mathrm{SrO}$ agglomerates and olive oil, biodiesel conversion is performed by an effective microwave heating; (c) product analysis and catalyst condition after the reaction were verified; (d) by acetone or ethanol cleaning under ultrasonic vibration, $\mathrm{SrO} / \mathrm{TiO}_{2} \mathrm{P}(\mathrm{x})$ could be reused.

\section{Experimental Section}

\subsection{Preparation of SrO Powder Deposited upon a Titanium Plate (SrO/TiO 2 P $)$}

Ti powder with a particle size of $\sim 45 \mu \mathrm{m}$ (Zhongrui Material Technology Corp., Tainan, Taiwan) was used. A Ti plate could be formed by the P/M method [17,59]. As illustrated in Figure 6a (1)-(4), for one plate, Ti powder of $0.5 \mathrm{~g}$ was compacted into a cylindrical disc of $\sim 10 \mathrm{~mm}$ in diameter and $\sim 7 \mathrm{~mm}$ in thickness; the compression stress was $200 \mathrm{MPa}$. The as-compacted sample is denoted as $\mathrm{TiO}_{2} \mathrm{cp}$. Then, $\mathrm{SrO}$ metal precursors were dipcoated on $\mathrm{TiO}_{2}$ ccp. Especially, $\mathrm{Sr}$ complexions were prepared by mixing strontium nitrate $\left(\mathrm{Sr}\left(\mathrm{NO}_{3}\right)_{2}, 99 \%\right.$, Aldrich, St. Louis, MO, USA) and deionized water (DI water) with 0.1, $0.3,0.5$, or $0.7 \mathrm{M} \mathrm{SrO}$ metal precursors. Afterward, $100 \mu \mathrm{L}$ of citric acid $\left(\mathrm{C}_{6} \mathrm{H}_{8} \mathrm{O}_{7}\right)$ was added for every $1 \mathrm{~mL}$ of the as-prepared solution. These mixed solutions were used for subsequent dip-coating of $\mathrm{SrO}$-containing solution on $\mathrm{TiO}_{2}$ c $\mathrm{cp}$ with a speed of $50 \mathrm{~mm} / \mathrm{min}$. The pre-coated samples, denoted as $\mathrm{SrO} / \mathrm{TiO}_{2} \mathrm{cp}(\mathrm{x})(\mathrm{x}=0.1,0.3,0.5$, or $0.7 \mathrm{M})$, were dried at $80^{\circ} \mathrm{C}$ for $20 \mathrm{~min}$ and then heat-treated at $1000{ }^{\circ} \mathrm{C}$ for $3 \mathrm{~h}$. The final products are denoted as $\mathrm{SrO} / \mathrm{TiO}_{2} \mathrm{P}(\mathrm{x})(\mathrm{x}=0.1,0.3,0.5$, or $0.7 \mathrm{M})$. 

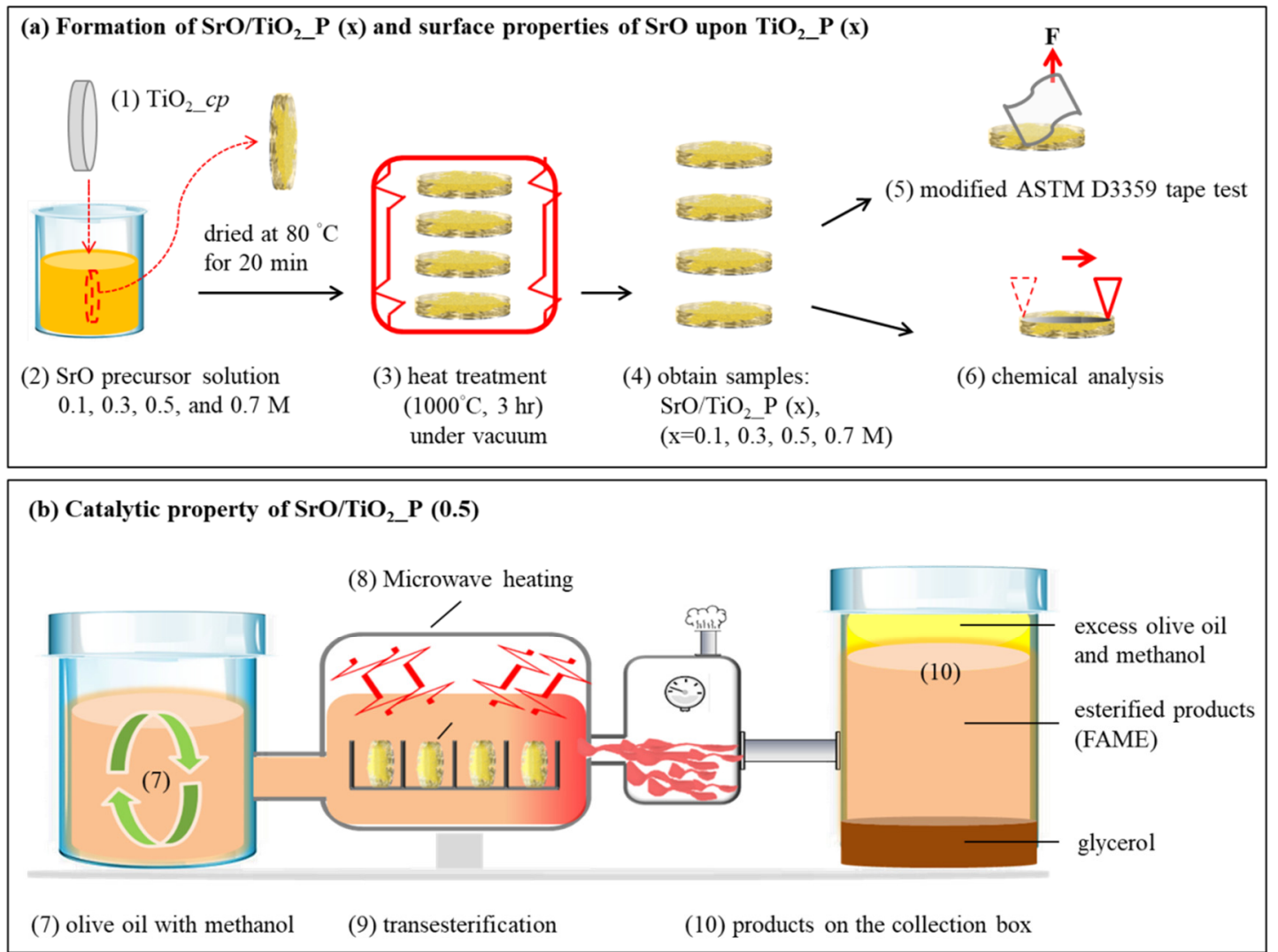

Figure 6. (a) The fabrication process and physical strength testing of $\mathrm{SrO} / \mathrm{TiO}_{2} \_\mathrm{P}(\mathrm{x})$ : (1) Pressing of $\mathrm{TiO}_{2}$ powder into a plate was $\left(\mathrm{TiO}_{2} \_\mathrm{p}\right)(2)$ then dipping into SrO precursor solution with different concentrations; (3) drying of $\mathrm{SrO} / \mathrm{TiO}{ }_{2}-\mathrm{p}(\mathrm{x})$ at $80{ }^{\circ} \mathrm{C}$ for $20 \mathrm{~min}$, then $1000{ }^{\circ} \mathrm{C}$ for $3 \mathrm{~h}$ under vacuum; (4) resulting samples were denoted as $\mathrm{SrO}_{-} \mathrm{TiO} \mathrm{O}_{2} \mathrm{P}(\mathrm{x}),(\mathrm{x}=0.1,0.3$, 0.5 , or $0.7 \mathrm{M}$ ); (5) adhesion strength between $\mathrm{SrO}_{2}$ and $\mathrm{TiO}_{2}$ P, tested through the modified ASTM D3359 tape test; (6) a roughness test was measured by using $\alpha$ step for $\mathrm{SrO}_{2}$ upon $\mathrm{TiO}_{2} \_\mathrm{P}$; (b) the catalytic property of $\mathrm{SrO} / \mathrm{TiO}{ }_{2} \_\mathrm{P}(0.5)$; (7) ratio of olive oil: methanol was maintained at 1:6; (8) focused microwave-assisted heating system was employed and measured as a function of reaction time; (9) transesterification reaction for biodiesel production; (10) collection of products (esterified products, FAME) and byproducts (glycerol, excess olive oil and methanol) for examination.

\subsection{Quality Assessment of $\mathrm{SrO}_{-} \mathrm{TiO}_{2} \mathrm{P}(x)$}

In Figure 6a (5), surface morphology of $\mathrm{SrO} / \mathrm{TiO}_{2} \_\mathrm{P}(\mathrm{x})$ were sputtered with a layer of $\mathrm{Pt}$ and then characterized by a field-emission scanning electron microscope (FE-SEM, JSM-7000, JEOL, Tokyo, Japan) with an accelerating voltage of $10 \mathrm{kV}$, under a chamber vacuum of $4.15 \times 10^{-3} \mathrm{~Pa}$. Crystalline structure of $\mathrm{SrO}_{-} \mathrm{TiO}_{2} \mathrm{P}(\mathrm{x})$ was determined using $\mathrm{X}$-ray diffraction with $\mathrm{CuK} \alpha$ radiation (XRD, D8 Discover, Bruker, Germany). In Figure 6a (6), chemical composition of $\mathrm{SrO}_{-} \mathrm{TiO}_{2} \mathrm{P}(\mathrm{x})$, before and after transesterification reaction, were characterized using X-ray photoelectron spectroscopy (XPS, PHI 5000, Versa Probe II, ULVAC-PHI, Incorporate,, Chigasaki, Japan) and Raman spectrometer with a confocal microscope (Renishaw, Gloucestershire, UK). For the former, $\mathrm{SrO}_{-} \mathrm{TiO}_{2} \_\mathrm{P}(\mathrm{x})$ were scanned with an exposure time of $10 \mathrm{sec}$ over an area of $1 \mu \mathrm{m} \times 1 \mu \mathrm{m}$, using a 50X objective. Ten consecutive measurements on different samples were averaged. All spectra were normalized using the peak fit software. The chemical bonds on the surfaces of $\mathrm{SrO}_{-} \mathrm{TiO}_{2} \mathrm{P}$ (x) were respectively characterized. The functionalities of constituent elements (i.e., $\mathrm{Sr}$ $3 \mathrm{~d}$ and $\mathrm{O} 1 \mathrm{~s}$ for the catalyst $\mathrm{SrO}$, Ti $2 \mathrm{p}$ for $\mathrm{TiO}_{2} \mathrm{P}$, and $\mathrm{C} 1 \mathrm{~s}$ and $\mathrm{O} 1 \mathrm{~s}$ for the reactants and products) were curve-fitted using the software Origin and related data information in order to clarify the formation of the esterification reaction. For the latter, Raman spectra were obtained using He-Ne and diode lasers with an excitation wavelength of $785 \mathrm{~nm}$. All Raman spectra were normalized using the PeakFit software. An air-cooled CCD was used as the detector and the incident power was $\sim 3 \mathrm{~mW}$. 


\subsection{Transesterification Reaction Measurement and Energy Conversion}

As illustrated in Figure 6b (7)-(10), the catalysis of $\mathrm{SrO}_{-} \mathrm{TiO}_{2} \_\mathrm{P}(\mathrm{x})$ in transesterification reaction was evaluated using olive oil (Taiwan Sugar Corp., Taiwan) as the reactant. In the experiment, the olive oil was mixed with methanol in a volume ratio of 1:6 and $\sim 3 \mathrm{wt} \%$ of SrO catalyst in $\mathrm{SrO}_{-} \mathrm{TiO}_{2} \_\mathrm{P}(\mathrm{x})$ and introduced into a built-in batch unit with a modified transesterification system, containing a microwave oven chamber with the capacity of $\sim 15 \mathrm{~mL}$. When microwave heating (i.e., for 1, 2,3, or $4 \mathrm{~min}$ ) was applied, the evaporated methanol and water were simultaneously cooled down to maintain the constancy of oil-tomethanol ratio by preventing methanol from the evaporative loss. Finally, the products were collected in a container.

Gas chromatography equipped with a flame ionization detector (GC-FID, GC-2014, Shimadzu, Japan) was employed to determine and verify the conversion efficiency of olive oil to biodiesel via the transesterification reaction. Note that the use of focused microwave heating tends to reduce the required power and time for the conversion, and thus decrease the output temperature from the reaction system.

The combustion heat of biodiesel was measured by bomb calorimeter (Model 1341, Parr Instrument Company, Moline, IL, USA) in accordance with the ASTM D240. After standardization with benzoic acid, samples with $0.5 \mathrm{~g}$ from each fuel were burned in the bomb. All measurements were repeated six times.

The water content in biodiesel was measured by Karl Fischer titrator (C30S Karl Fisher titrator, Zurich, Switzerland). The highest accuracy of moisture determination is equivalent to a relative standard deviation of $1.48 \%$. Other parameters (e.g., extraction time) have little or no effect on improving the accuracy of moisture determination.

The samples was cleaned on EtOH or Acetone aqueous (Ultrasonic, DC-300H, Delta, Taiwan) under ultrasonic vibration $(40 \mathrm{kHz})$ at $10 \mathrm{~min}$.

\section{Conclusions}

Titanium powder can be formed into a $\mathrm{TiO}_{2}$ plate $\left(\mathrm{TiO}_{2} \mathrm{P}\right)$ as a load-bearable support and designed to integrate with catalytic $\mathrm{SrO}$ agglomerates $(\mathrm{SrO})$. The synergic effect of SrO agglomerates with $\mathrm{TiO}_{2}$ plate $\left(\mathrm{SrO} / \mathrm{TiO}_{2} \mathrm{P}\right)$ is realized by forming $\mathrm{SrTiO}_{3}$ phase at their interface and most of the exposed and dispersed $\mathrm{SrO}$ agglomerates on the upper part are in full contact with olive oil. By applying effective focused microwave heating, the transesterification reaction process is carried out in a batch mode. Then, before and after the transesterification process, the optimized surface of $\mathrm{SrO} / \mathrm{TiO}_{2} \mathrm{P}(0.5)$ is characterized by XPS study, so that the reactions can be interpreted. The quality of the as-produced biodiesel is examined by the characteristic Raman peak, conversion rate, combustion heat, and water content. The report is promising, however, there is still room for effort in the biodiesel production process. Moreover, the by-products derived from the reactions can be collected for other applications, while the used $\mathrm{SrO} / \mathrm{TiO}_{2} \_\mathrm{P}$ can be cleaned and mostly re-cyclable for subsequent uses. This innovative and re-cyclable design can thus promote production efficiency of biodiesel.

Author Contributions: Conceptualization, H.L. and W.-H.W.; methodology, W.-H.W.; software, H.L. and W.-H.W.; formal analysis, H.L. and W.-H.W.; investigation, W.-H.W.; data collection, H.L. and W.-H.W.; writing—original draft preparation, H.L. and J.-D.L.; writing—review and editing, B.-H.C. and J.-D.L.; supervision, B.-H.C.; project administration, J.-D.L. All authors have read and agreed to the published version of the manuscript.

Funding: This research received no external funding.

Acknowledgments: This work was supported by the Ministry of Science and Technology of Taiwan (grant number: MOST 108-2218-E-006-054-MY3 and 109-2811-E-006-531-MY2).

Conflicts of Interest: The authors declare no conflict of interest. 


\section{References}

1. Olabi, A.G. Circular economy and renewable energy. Energy 2019, 181, 450-454. [CrossRef]

2. Astolfi, V.; Astolfi, A.L.; Mazutti, M.A.; Rigo, E.; Di Luccio, M.; Camargo, A.F.; Dalastra, C.; Kubeneck, S.; Fongaro, G.; Treichel, H. Cellulolytic enzyme production from agricultural residues for biofuel purpose on circular economy approach. Bioprocess Biosyst. Eng. 2019, 42, 677-685. [CrossRef] [PubMed]

3. Huang, B.; Wang, X.; Kua, H.; Geng, Y.; Bleischwitz, R.; Ren, J. Construction and demolition waste management in China through the 3R principle. Resour. Conserv. Recycl. 2018, 129, 36-44. [CrossRef]

4. Rastogi, R.P.; Pandey, A.; Larroche, C.; Madamwar, D. Algal green energy-R\&D and technological perspectives for biodiesel production. Renew. Sustain. Energy Rev. 2018, 82, 2946-2969.

5. Anto, S.; Mukherjee, S.S.; Muthappa, R.; Mathimani, T.; Deviram, G.; Kumar, S.S.; Verma, T.N.; Pugazhendhi, A. Algae as green energy reserve: Technological outlook on biofuel production. Chemosphere 2020, 242, 125079. [CrossRef]

6. Shachi, S.; Venkatramanan, V.; Ram, P. Sustainable Green Technologies for Environmental Management; Springer: Singapore, 2019; ISBN 978-981-13-2772-8.

7. Sharma, P.K.; Kuinkel, H.; Shrestha, P.; Poudel, S. Use of acetylene as an alternative fuel in IC engine. Mech. Confab. 2012, 1, 19-22.

8. Xin, C.; Addy, M.M.; Zhao, J.; Cheng, Y.; Ma, Y.; Liu, S.; Mu, D.; Liu, Y.; Chen, P.; Ruan, R. Waste-to-biofuel integrated system and its comprehensive techno-economic assessment in wastewater treatment plants. Bioresour. Technol. 2018, 250, 523-531. [CrossRef]

9. Cao, Y.; Doustgani, A.; Salehi, A.; Nemati, M.; Ghasemi, A.; Koohshekan, O.; Jamali, D.H. The economic evaluation of establishing a plant for producing biodiesel from edible oil wastes in oil-rich countries: Case study Iran. Energy 2020, 213, 118760. [CrossRef]

10. Fawaz, E.G.; Salam, D.A. Preliminary economic assessment of the use of waste frying oils for biodiesel production in Beirut, Lebanon. Sci. Total Environ. 2018, 637-638, 1230-1240. [CrossRef]

11. Aydin, H. Scrutinizing the combustion, performance and emissions of safflower biodiesel-kerosene fueled diesel engine used as power source for a generator. Energy Convers. Manag. 2016, 117, 400-409. [CrossRef]

12. Aydin, S. Detailed evaluation of combustion, performance and emissions of ethyl proxitol and methyl proxitol-safflower biodiesel blends in a power generator diesel engine. Fuel 2020, 270, 117492. [CrossRef]

13. Masiero, G. Developments of biofuels in Brazil and East Asia: Experiences and challenges. Rev. Bras. Polit. Int. 2011, 54, 97-117. [CrossRef]

14. Ecofys. Technical Assistance in Realisation of the 2018 Report on Biofuels Sustainability; Ecofys-A Navigant Company: Utrecht, The Netherlands, 2019; p. 141.

15. Bušić, A.; Kundas, S.; Morzak, G.; Belskaya, H.; Mardetko, N.; Šantek, M.I.; Komes, D.; Novak, S.; Šantek, B. Recent trends in biodiesel and biogas production. Food Technol. Biotechnol. 2018, 56, 152-173. [CrossRef] [PubMed]

16. Lee, H.; Liao, J.D.; Yang, J.W.; Hsu, W.D.; Liu, B.H.; Chen, T.C.; Sivashanmugan, K.; Gedanken, A. Continuous waste cooking oil transesterification with microwave heating and strontium oxide catalyst. Chem. Eng. Technol. 2018, 41, 192-198. [CrossRef]

17. Lee, H.; Liao, J.D.; Lee, M.H.; Liu, B.H.; Fu, W.E.; Sivashanmugan, K.; Juang, Y.D. Der Strontium oxide deposited onto a loadbearable and porous titanium matrix as dynamic and high-surface-contact-area catalysis for transesterification. Nanomaterials 2018, 8, 973. [CrossRef]

18. Benjumea, P.; Agudelo, J.; Agudelo, A. Basic properties of palm oil biodiesel-diesel blends. Fuel 2008, 87, 2069-2075. [CrossRef]

19. Fernando, S.; Hanna, M. Development of a novel biofuel blend using ethanol-biodiesel-diesel microemulsions: EB-diesel. Energy Fuels 2004, 18, 1695-1703. [CrossRef]

20. Jahirul, M.I.; Rasul, M.G.; Chowdhury, A.A.; Ashwath, N. Biofuels production through biomass pyrolysis-A technological review. Energies 2012, 5, 4952-5001. [CrossRef]

21. Tantirungrotechai, J.; Thepwatee, S.; Yoosuk, B. Biodiesel synthesis over Sr/MgO solid base catalyst. Fuel 2013, 106, 279-284. [CrossRef]

22. Liu, X.; He, H.; Wang, Y.; Zhu, S. Transesterification of soybean oil to biodiesel using SrO as a solid base catalyst. Catal. Commun. 2007, 8, 1107-1111. [CrossRef]

23. Abbaszaadeh, A.; Ghobadian, B.; Omidkhah, M.R.; Najafi, G. Current biodiesel production technologies: A comparative review. Energy Convers. Manag. 2012, 63, 138-148. [CrossRef]

24. Laskar, I.B.; Deshmukhya, T.; Bhanja, P.; Paul, B.; Gupta, R.; Chatterjee, S. Transesterification of soybean oil at room temperature using biowaste as catalyst; an experimental investigation on the effect of co-solvent on biodiesel yield. Renew. Energy 2020, 162, 98-111. [CrossRef]

25. Al-Saadi, A.; Mathan, B.; He, Y. Esterification and transesterification over $\mathrm{SrO}-\mathrm{ZnO} / \mathrm{Al}_{2} \mathrm{O}_{3}$ as a novel bifunctional catalyst for biodiesel production. Renew. Energy 2020, 158, 388-399. [CrossRef]

26. Falowo, O.A.; Oloko-Oba, M.I.; Betiku, E. Biodiesel production intensification via microwave irradiation-assisted transesterification of oil blend using nanoparticles from elephant-ear tree pod husk as a base heterogeneous catalyst. Chem. Eng. Process. Process Intensif. 2019, 140, 157-170. [CrossRef]

27. Sharma, A.; Kodgire, P.; Kachhwaha, S.S. Biodiesel production from waste cotton-seed cooking oil using microwave-assisted transesterification: Optimization and kinetic modeling. Renew. Sustain. Energy Rev. 2019, 116, 109394. [CrossRef]

28. Nomanbhay, S.; Ong, M.Y. A review of microwave-assisted reactions for biodiesel production. Bioengineering 2017, $4,57$. [CrossRef] 
29. Mirzaei, A.; Neri, G. Microwave-assisted synthesis of metal oxide nanostructures for gas sensing application: A review. Sens. Actuators B Chem. 2016, 237, 749-775. [CrossRef]

30. Lee, D.W.; Park, Y.M.; Lee, K.Y. Heterogeneous base catalysts for transesterification in biodiesel synthesis. Catal. Surv. Asia 2009, 13, 63-77. [CrossRef]

31. Vicente, G.; Martínez, M.; Aracil, J. Integrated biodiesel production: A comparison of different homogeneous catalysts systems. Bioresour. Technol. 2004, 92, 297-305. [CrossRef]

32. Singh, A.; He, B.; Thompson, J.; van Gerpen, J. Process optimization of biodiesel production using alkaline catalysts. Appl. Eng. Agric. 2006, 22, 597-600. [CrossRef]

33. Srivastava, A.; Prasad, R. Triglycerides-based diesel fuels. Renew. Sustain. Energy Rev. 2000, 4, 111-133. [CrossRef]

34. Soriano, N.U.; Venditti, R.; Argyropoulos, D.S. Biodiesel synthesis via homogeneous Lewis acid-catalyzed transesterification. Fuel 2009, 88, 560-565. [CrossRef]

35. Lin, C.-Y.; Ma, L. Influences of water content in feedstock oil on burning characteristics of fatty acid methyl esters. Processes 2020, 8, 1130. [CrossRef]

36. Gülüm, M.; Bilgin, A. Regression models for predicting some important fuel properties of corn and hazelnut oil biodiesel-Diesel fuel blends. Exergetic Energ. Environ. Dimens. 2018, 829-850. [CrossRef]

37. Chouhan, A.P.S.; Sarma, A.K. Modern heterogeneous catalysts for biodiesel production: A comprehensive review. Renew. Sustain. Energy Rev. 2011, 15, 4378-4399. [CrossRef]

38. Tangy, A.; Pulidindi, I.N.; Gedanken, A. $\mathrm{SiO}_{2}$ Beads decorated with $\mathrm{SrO}$ nanoparticles for biodiesel production from waste cooking oil using microwave irradiation. Energy Fuels 2016, 30, 3151-3160. [CrossRef]

39. Li, H.; Liu, F.; Ma, X.; Wu, Z.; Li, Y.; Zhang, L.; Zhou, S.; Helian, Y. Catalytic performance of strontium oxide supported by MIL-100(Fe) derivate as transesterification catalyst for biodiesel production. Energy Convers. Manag. 2019, 180, 401-410. [CrossRef]

40. Thangaraj, B.; Solomon, P.R.; Muniyandi, B.; Ranganathan, S.; Lin, L. Catalysis in biodiesel production-A review. Clean Energy 2019, 3, 2-23. [CrossRef]

41. Koberg, M.; Abu-Much, R.; Gedanken, A. Optimization of bio-diesel production from soybean and wastes of cooked oil: Combining dielectric microwave irradiation and a SrO catalyst. Bioresour. Technol. 2011, 102, 1073-1078. [CrossRef]

42. Faungnawakij, K.; Yoosuk, B.; Namuangruk, S.; Krasae, P.; Viriya-empikul, N.; Puttasawat, B. Sr-Mg mixed oxides as biodiesel production catalysts. Chem. Cat. Chem. 2012, 4, 209-216. [CrossRef]

43. Martinez-Guerra, E.; Gude, V.G. Transesterification of used vegetable oil catalyzed by barium oxide under simultaneous microwave and ultrasound irradiations. Energy Convers. Manag. 2014, 88, 633-640. [CrossRef]

44. Dossin, T.F.; Reyniers, M.F.; Berger, R.J.; Marin, G.B. Simulation of heterogeneously MgO-catalyzed transesterification for fine-chemical and biodiesel industrial production. Appl. Catal. B Environ. 2006, 67, 136-148. [CrossRef]

45. Kouzu, M.; Hidaka, J.S. Transesterification of vegetable oil into biodiesel catalyzed by CaO: A review. Fuel 2012, 93, 1-12 [CrossRef]

46. Shobhana-Gnanaserkhar; Asikin-Mijan, N.; AbdulKareem-Alsultan, G.; Sivasangar-Seenivasagam; Izham, S.M.; Taufiq-Yap, Y.H. Biodiesel production via simultaneous esterification and transesterification of chicken fat oil by mesoporous sulfated Ce supported activated carbon. Biomass Bioenergy 2020, 141, 105714. [CrossRef]

47. Fadhil, A.B.; Aziz, A.M.; Altamer, M.H. Optimization of methyl esters production from non-edible oils using activated carbon supported potassium hydroxide as a solid base catalyst. Arab. J. Basic Appl. Sci. 2018, 25, 56-65. [CrossRef]

48. Xuewen, W.; Zhiyong, Z.; Shuixian, Z. Preparation of nano-crystalline $\mathrm{SrTiO}_{3}$ powder in sol-gel process. Mater. Sci. Eng. B Solid State Mater. Adv. Technol. 2001, 86, 29-33. [CrossRef]

49. Bagherisereshki, E.; Tran, J.; Lei, F.; AuYeung, N. Investigation into $\mathrm{SrO} / \mathrm{SrCO}_{3}$ for high temperature thermochemical energy storage. Sol. Energy 2018, 160, 85-93. [CrossRef]

50. Vasquez, R.P. X-ray photoelectron spectroscopy study of Sr and Ba compounds. J. Electron Spectros. Relat. Phenomena 1991, 56, 217-240. [CrossRef]

51. Fuentes, S.; Chávez, E.; Padilla-Campos, L.; Diaz-Droguett, D.E. Influence of reactant type on the Sr incorporation grade and structural characteristics of $\mathrm{Ba1}_{-\mathrm{xSrxTiO}}(\mathrm{x}=0$-1) grown by sol-gel-hydrothermal synthesis. Ceram. Int. 2013, 39, 8823-8831. [CrossRef]

52. Montero, J.M.; Isaacs, M.A.; Lee, A.F.; Lynam, J.M.; Wilson, K. The surface chemistry of nanocrystalline MgO catalysts for FAME production: An in situ XPS study of $\mathrm{H}_{2} \mathrm{O}, \mathrm{CH}_{3} \mathrm{OH}$ and $\mathrm{CH}_{3} \mathrm{OAc}$ adsorption. Surf. Sci. 2016, 646, 170-178. [CrossRef]

53. Fereidooni, L.; Tahvildari, K.; Mehrpooya, M. Trans-esterification of waste cooking oil with methanol by electrolysis process using KOH. Renew. Energy 2018, 116, 183-193. [CrossRef]

54. Ghesti, G.F.; De Macedo, J.L.; Braga, V.S.; De Souza, A.T.C.P.; Parente, V.C.I.; Figuerêdo, E.S.; Resck, I.S.; Dias, J.A.; Dias, S.C.L. Application of Raman spectroscopy to monitor and quantify ethyl esters in soybean oil transesterification. JAOCS J. Am. Oil Chem. Soc. 2006, 83, 597-601. [CrossRef]

55. Mollaeian, K.; Wei, S.; Islam, M.R.; Dickerson, B.; Holmes, W.E.; Benson, T.J. Development of an online raman analysis technique for monitoring the production of biofuels. Energy Fuels 2016, 30, 4112-4117. [CrossRef]

56. Sivaramakrishnan, K. Determination of higher heating value of biodiesels. Int. J. Eng. Sci. Technol. 2011, 3, 7981-7987. 
57. Fregolente, P.B.L.; Fregolente, L.V.; Wolf MacIel, M.R. Water content in biodiesel, diesel, and biodiesel-diesel blends. J. Chem. Eng. Data 2012, 57, 1817-1821. [CrossRef]

58. Lin, C.; Tsai, S. Production of biodiesel from chicken wastes by various alcohol-catalyst combinations. J. Energy South. Afr. 2015, 26, 36-45. [CrossRef]

59. Duz, V.A.; Moxson, V.S. The direct powder rolling process for producing titanium and titanium alloy foils, sheets and plates. Mater. Sci. Technol. 2005, 4, 45-53. 